\title{
Dative Arguments in Turkish: Caused Experiencers versus Applicatives
}

\author{
Faruk Akkuş*
}

\begin{abstract}
This paper investigates a type of construction in Turkish which is similar to Ingason's (2016) 'caused experience' construction in Icelandic. The study draws a distinction between experiencers and applicatives through an investigation of novel data, and contends that these two arguments occupy distinct syntactic positions in the structure. The caused experiencers in Turkish are introduced by the syntactic head Aff(ect) of whereas applicatives are introduced by the Applicative head (Pylkkänen 2008). The proposal also captures the at-issue meaning of the sentence as well as not-at-issue meaning (an implicature) of the sentence.
\end{abstract}

Keywords. dative arguments; applicatives; caused experiencer; AffectP; Turkish

1. Introduction. Languages allow an NP that is not selected by the verb to be added to a clause, and the NP might express different interpretations. In this paper, I distinguish two types of NPs in Turkish, and argue that one type of NP is a caused experiencer, (1), whereas the other one is an applicative argument, as illustrated in (2).

caused experiencer

a. O-na gıcıklı̆̆-ın-a, yani sirf o-nu gicık et-mek uğrun-a en iyi he-DAT irritation-POSS-DAT that.is just he-ACC irritation do-INF goal-DAT most good arkadaş-1-yla öp-üş-tü-m. friend-3POSS-COM kiss-REC-PST-1sG 'To his irritation, just to irritate him, I kissed his best friend.'

b. Adam-lar ban-a sinir-in-e 4 defa torba-ya koy-muş-lar kargo-m-u. man-PL I-DAT anger-POSS-DAT four time bag-DAT put-PERF-PL package-1POss-ACC 'The men wrapped my package four times in a bag to my anger.' ${ }^{1}$

(2) (benefactive) applicative

Başbakan-ımız-a dans et-mek isti-yor-um.

prime minister-1POSS.PL-DAT dance do-INF want-PROG-1SG

'I'd like to dance for our Prime Minister.' (Tonyal 2015:22)

As the paraphrase in (1a) makes clear, a salient reading is that the woman performs an event, i.e. 'kissing the best friend', with the intention/purpose of causing another event/state, i.e. 'the irritation of her boyfiend'. ${ }^{2}$ Similarly, the salient reading in (1b) is that the men, referring to the customs officers, performed an event of wrapping a package in such a way that this event leads to a state in which the speaker feels annoyed. Note that there is no acquaintance between the participants.

\footnotetext{
*I would like to thank Florian Schwarz, Julie Anne Legate, Aslı Göksel, Alison Biggs, Richard Larson and the anonymous reviewers of the volume for discussions and invaluable suggestions. Also thanks to Mehmet Köse, Asli Göksel, Bülent Akkuş, Hasan Yıldırım, and also the Turkish reviewer of Tu+4 for some points about this construction and/or judgments. Thanks to the organizers of Tu+4, Paloma Jereti and Yamur Sa for their help. Usual disclaimers apply. Author: Faruk Akkuş, University of Pennsylvania (akkusf@sas.upenn.edu).

${ }^{1} \mathrm{http} / / /$ www.heliteknik.com/forum/archive/index.php/t-6464.html. Retrieved on October 15, 2017.

${ }^{2}$ For some speakers, this construction has another salient reading, in which the feeling is experienced by the agent, and not by another experiencer as a result of the action performed by the agent. An anonymous reviewer asks if this variation could be related to the person, given that in one example the subject is 1st person, whereas in the other one it is 3rd person. As far as I can tell, this does not depend on the choice of person, however, I put this interpretation and a detailed investigation of it aside in this paper.
} 
As such, the customs officers wrap the package in the way they do without necessarily anticipating its effect on the person receiving the package. Thus, it is not necessary for the participants to be in an acquaintance relationship for the felicity of this construction. On the other hand, (2) is an applicative construction which will be shown to differ in several aspects. (3) - (5) illustrate scenarios in which the agent of the causing event and the experiencer of the ensuing state know each other, and the agent of the causing event is most likely aware of the experience their action will generate for another individual.

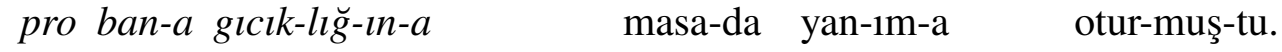

I-DAT irritation-DER-POSS-DAT table-LOC side-1POSS-DAT sit.down-PERF-PST

'S/he sat by my side at the table to my irritation.'

(4) pro ban-a sinir-in-e evlen-iyor!

I-DAT anger-POSS-DAT marry-PROG

'S/he is getting married to my anger.'

(5) $\mathrm{Bu}$ saçma sapan hareket-ler-i de ban-a uyuzluğ-un-a.

this nonsensical behavior-PL-3POss also I-DAT annoyance-POSS-DAT

'These nonsensical behavior of his/hers are to my annoyance.'

The caused experiencer receives dative case and is contained in a nominal structure of the form "NP-DAT experienced eventuality-POSs-DAT" (see section 4.3 for the structure). This structure expresses an experienced eventuality via various roots, such as inat 'spite', hınç 'resentment', haset 'jealousy', sinir 'anger', glcıklık 'irritation' or uyuzluk 'annoyance'. Following Ingason's (2016) label for a parallel construction in Icelandic, I call them caused experience (CEx) (see also the label that affected experiencer Bosse, Bruening \& Yamada (2012) use for a similar construction in several languages).

I demonstrate that caused experiencers differ from the more canonical applied arguments (Pylkkänen 2002, 2008) in terms of several syntactic and semantic aspects. CEx are introduced in Aff(ect)P of Bosse \& Bruening (2011), Bosse, Bruening \& Yamada (2012), whereas benefactives/malefactives are introduced by the Applicative head (Pylkkänen 2008).

The paper is organized as follows: $\S 2$ elaborates on the syntax of non-core datives, and focuses on the distributional differences between them. $\S 3$ investigates the semantic properties of these two DPs. $\$ 4$ demonstrates that the experiencer is introduced in a nominal structure, independently of a verbal property. $\$ 5$ implements the syntax and semantics of both the CEx and applicatives. $\$ 6$ summarizes and concludes the paper.

2. Syntax of non-core datives. This section investigates the properties of two types of dative arguments.

2.1. Applicatives. A non-core dative argument can be added to the stative verb tut- 'hold':

(6) Kemal Hasan için / Hasan-a şemsiye-yi tut-tu.

Kemal Hasan for / Hasan-DAT umbrella-ACC hold-PST

'Kemal held the umbrella for Hasan.'

It can also combine with unergatives. 
(7) O-na çalış-1yor-um

s/he-DAT work-PROG-1SG

'I am working for his/her benefit.'

It can also combine with dynamic or stative unaccusatives, as in (8), but not inchoatives, e.g. break, die, fall, as illustrated in (9).

(8) a. benefactive

Öğrenci-ye büyük ikramiye çık-tı.

student-DAT big prize emerge/appear/come

'A student won/got the biggest lottery prize.' (Tonyal 2015:38)

b. malefactive

İş yine ban-a kal-d1.

work again I-DAT remain-PST

'The work remains for me (to do) again.'

(9) a. *Ayşe-ye vazo kır-1l-d1.

Ayşe-DAT vase break-PASs-PST

Intended: 'The vase broke on Ayşe accidentally.' (ibid.:102)

b. Asker vatan-1 için /*vatan-ın-a öl-dü.

soldier country-3Poss for $/ *$ country-3POss-DAT die-PST.3SG

'The soldier died for his country.' ${ }^{3}$

Given the compatibility with unergatives and stative verbs, I assume (following Tonyal (2015)) that these non-core datives appear in a high applicative construction. Only high applicatives can combine with these two verb types in addition to transitives (Pylkkänen 2008).

In order to incorporate non-core arguments into the syntax, Pylkkänen $(2002,2008)$ proposes that cross-linguistically languages exhibit two types of applicative constructions: (i) low applicatives, which denote a relation between two individuals, necessarily implying a transfer of To or FROM the possession of and (ii) high applicatives, which denote a relation between an individual and an event, being introduced above the VP. Given that high applicatives are relevant for the discussion in this paper, their structure is given in (10).

(10) High-applicative (Pylkkänen 2008: (13))

a.

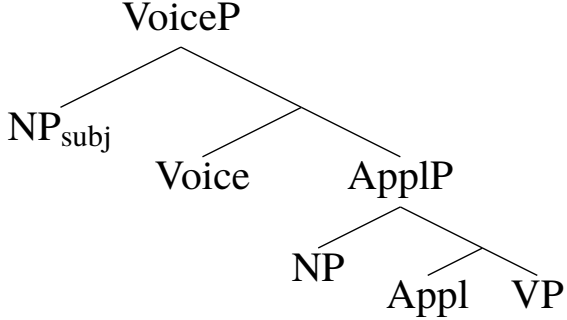

b. $\quad[[$ Appl $]]=\lambda \mathrm{P}_{\mathrm{vt}} \cdot \lambda \mathrm{x} \cdot \lambda \mathrm{e} \cdot \mathrm{P}(\mathrm{e}) \&$ Appl. $(\mathrm{x})(\mathrm{e})$

Pylkkänen (2008) suggests that dative experiencers/benefactives/malefactives are introduced as specifiers of high applicatives, whereas for instance, the indirect objects of the double-object

${ }^{3} \mathrm{cf}$. a recently-developing usage as in (i), in which there is a more agentive reading of to die.

(i) Ben san-a öl-ür-üm ya!

I you-DAT die-AOR-1sG excl

'I'd die for you!' 
construction in English are introduced in the specifier of low applicatives. Finally, ApplP/VP and Voice combine by the rule of Event Identification (Kratzer 1996).

Let us turn to distributional and interpretational diagnostics, which demonstrate that affected experiencers are of a different category than applied arguments.

2.2. Distributional Differences. The distributional properties of the two constructions demonstrate that the two dative arguments in this paper belong to separate categories.

First, they differ in terms of the host structure: the applicative argument simply has the form of a dative-case marked DP, e.g. (1b). The caused experiencer, however, is expressed in a more articulated structure, which contains an experience predicate in addition to the experiencer argument itself, e.g. (1a).

Second, applicatives and experiencers differ with regard to the types of predicate they are compatible with. Applicatives can't occur with change of state (inchoative) predicates, as illustrated in $(11) .^{4}$
a. *Kemal Hasan-a öl-dü.
Kemal Hasan-DAT die-PST
'Kemal died for Hasan.'
b. *Elma ağaç-tan sanki kadın-a düş-tü.
apple tree-ABL as if woman-DAT fall-PST
'The apple fell from the tree as if for the woman.'

On the other hand, experiencers impose no such restriction, seen in (12).
a. Kemal ban-a inad-ın-a öl-dü.
Kemal I-DAT spite-POSS-DAT die-PST
'Kemal died to spite me.'
b. Şimşek sanki ban-a gicıklı̆̆-ın-a çarp-tı.
lightning as if I-DAT irritation-POSS-DAT strike-PST
'The lightning struck as if to my irritation.'

Third, these two dative arguments can co-occur in the same clause, i.e. are not mutually exclusive. Consider (13).
a. Ban-a gicıklığ-ın-a
Hasan-a şemsiye-yi tut-tu.
I-DAT irritation-POSS-DAT Hasan-DAT umbrella-ACC hold-PST
'S/he held the umbrella for Hasan to my irritation.'
b. Kemal ban-a sinir-in-e Hasan-a dans et-ti.
Kemal I-DAT anger-Poss-DAT Hasan-DAT dance do-PST
'Kemal danced for Hasan to my anger.'

A further piece of evidence for the two datives being of distinct nature comes from coordination. Following the standard approach to coordination, two (or more) elements of the same category can be coordinated. This is confirmed by (14) and (15), where two applicatives or caused experiencers, respectively, are coordinated.

(14) [Ban-a ve Hasan-a] şemsiye-yi tut-tu.

I-DAT and Hasan-DAT umbrella-ACC hold-PST

'S/he held the umbrella for me and Hasan.'

\footnotetext{
${ }^{4}$ As noted by an anonymous reviewer, both of these sentences are fine with the postposition için 'for' instead of the dative case.
} 
[Ban-a gicıklığ-1n-a ve Hasan-a inad-in-a] şemsiye-yi tut-tu.

I-DAT irritation-POSS-DAT and Hasan-DAT spite-POSS-DAT umbrella-ACC hold-PST 'S/he held the umbrella to my irritation and to Hasan's spite.

However, coordination of an applicative argument and a CEx leads to ungrammaticality.
*[Ban-a giciklığ-in-a
ve Hasan-a
şemsiye-yi
tut-tu.
I-DAT irritation-POSS-DAT and Hasan-DAT umbrella-ACC hold-PST
'S/he held the umbrella for Hasan and to my irritation.'

The diagnostics in this section demonstrate that in terms of their distributional properties, the two dative-bearing elements belong to distinct categories. The next section looks at the structure Bosse, Bruening \& Yamada (2012), Bosse \& Bruening (2011) suggest for DPs resembling caused experiencers in several languages. I take their structure as a starting point and modify it slightly to capture the pattern in Turkish (see section 4.2).

2.3. The syntax of AffectP. Bosse, Bruening \& Yamada (2012), Bosse \& Bruening (2011) deal with similar considerations for mainly German, Hebrew and Japanese. They propose that experiencers are introduced by a syntactic head Aff(ect), which can merge with VP or VoiceP, as illustrated in (17a) and (17b), respectively. This head introduces an experiencing event and an experiencer.
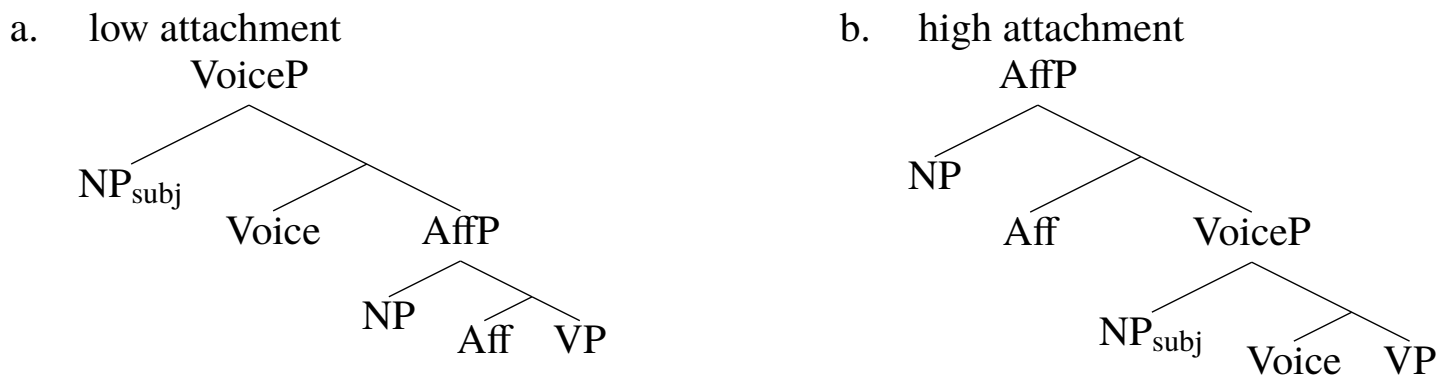

The variation in the attachment site for Aff is related to an interpretational difference between German and Japanese in the source information. In German (18), the agent Alex is not included in the source of the psychological feeling of the affected argument Chris. The default assumption is that what matters to Chris is that Ben's vase was broken; it would matter to him regardless of who did it. This is not the case in Japanese (19), where the agent Masa is included in the source information.
Alex zerbrach Chris Bens Vase.
Alex broke Chris.DAT Ben.gen vase.ACC
'Alex broke Ben's vase and...
1. ... it matters to Chris because it was Ben's vase.'
2. ... \#it matters to Chris because Alex did it.' (Bosse, Bruening \& Yamada 2012: (65)) 
Sachi-wa Masa-ni Aiko-no kabin-o kowas-are-ta.

Sachi-top Masa-DAt Aiko-GEN vase-GEN break-AFF-PST

'Sachi had Masa break Aiko's vase on him and ...

1. ... it matters to Sachi because it was Aiko's vase.'

2. ... it matters to Sachi because Masa did it.' (Bosse, Bruening \& Yamada 2012: (66))

Bosse, Bruening \& Yamada (2012) note that the judgments are subtle across languages since actual contexts can make the agent more or less relevant. Turning to Turkish, we observe that the judgments are indeed quite subtle and that there is inter-speaker variation. ${ }^{5}$
Kemal ban-a gicıklığ-ın-a
Leyla'nın vazo-sun-u kir-dı.
Kemal I-DAT irritation-POSS-DAT Leyla-GEN vase-POSS-ACC break-PST
'Kemal broke Leyla's vase and ...
1. ... it matters to me because it was Leyla's vase.'
2. ... it matters to me because Kemal did it.'

For the sake of exposition, I adopt a low attachment site for AffP (with the caveat that I will assume adjunction of AffP, and a more articulated AffP since in Turkish the experiencing event itself is overtly realized. See section 5).

3. The semantics of non-core datives. This section examines the semantic properties of CEx in comparison with applied arguments.

3.1. Interpretational properties. Several meaning-related diagnostics demonstrate that experiencers and applicatives differ (diagnostics from Potts 2005 and Bosse, Bruening \& Yamada 2012).

The first difference relates to sentience. Benefactives do not require that the non-selected argument be sentient and aware, as in (21).
Kemal sınıf-a / merhum baba-sın-a çiçek topla-di.
Kemal class-DAT / dead father-3Poss-DAT flower pick-PST
'Kemal picked some flowers for the class / his late father.' (father can be dead at the time of picking)

Affected experiencers require the argument to be sentient and aware. (22a) is infelicitous because the father is dead, and (22b) because the door is non-sentient. The former sentence would become felicitous in a context where the father is not dead. Similarly, (22b) becomes felicitous only if some sentience is attributed to the door.
a. \#Kemal merhum baba-sin-a
giciklığ-ın-a
ev-i sat-ti.
Kemal dead father-3Poss-DAT irritation-POSS-DAT house-ACC sell-PST
'Kemal sold the house to the irritation of his late father.'
b. \#Adam kapı-ya inad-ın-a kapı kol-un-u değiştir-me-di
man door-DAT spite-POSS-DAT door handle-CM-ACC replace-NEG-PST
'The man didn't replace the door handle to spite the door.'

The two dative constructions also vary in terms of not-at-issue meaning. The benefactive relation can be negated to the exclusion of the main verbal event, and thus can have the available reading in (23).

\footnotetext{
${ }^{5}$ Out of 4 speakers, 2 speakers (Mehmet Köse and myself) pattern like German in that the identity of the agent is not crucial, whereas 2 (Bülent Akkuş, Hasan Yıldırım) have judgments that pattern more like Japanese (as such what matters is the existence of an event that leads to an experiencing event.)
} 
(23) Kemal Hasan-a şemsiye-yi tut-ma-d1.

Kemal Hasan-DAT umbrella-ACC hold-NEG-PST

'Kemal didn't hold the umbrella for Hasan.'

(Kemal held the umbrella, but not for Hasan)

On the other hand, under neutral intonation, in (24), it is not possible to negate the experience itself; rather, the whole verbal event is negated. Thus, the meaning of experience projects past negation. ${ }^{6}$

Kemal Hasan-a inad-1n-a öl-me-di.

Kemal Hasan-DAT spite-POSS-DAT die-NEG-PST

'Kemal didn't die on Hasan.'

i. Kemal didn't die, but if he had it would have angered/mattered to Hasan.

ii. *Kemal died, but it didn't anger/matter to Hasan.

In order to negate the affected experiencer, we need to add de ğil 'not'.

Kemal Hasan-a inad-ın-a değil, Murat-a inad-ın-a öl-me-di.

Kemal Hasan-DAT spite-POSS-DAT not Murat-DAT spite-POSs-DAT die-NEG-PST

'Kemal didn't die, not to spite Hasan, but Murat.'

Interestingly, similar to benefactives, experiencers can also contribute some at-issue meaning. As such, they can be questioned as wh-phrases, (26), (Bosse \& Bruening 2011:73).

Leyla kim-e gicıklı̆̆-ın-a araba-yı satın al-dı?

Leyla who-DAT irritation-POSS-DAT car-ACC purchase take-PST?

'To whose irritation did Leyla buy the car?'

As expected, benefactives can also be questioned.

Leyla program-1 kim-e kur-du?

Leyla program-ACC who-DAT install-PST

'Who did Leyla install the program for?'

To summarize, the distributional and interpretational differences demonstrate that the affected experiencers and applied arguments are of different natures. This warrants identifying them in two distinct projections, with different semantic contribution. The next section investigates the structure in which the experiencer is contained. This is because it is generally assumed that applicatives and related arguments are part of the extended projection of the verb.

3.2. The Semantics of AffP. I take the semantic denotation provided in Bosse, Bruening \& Yamada (2012) as a starting point. In that model, Aff takes the event property denoted by its sister constituent to be the source of the affected experiencer's experience via a conventional implicature. In order to capture these components, the denotation in (28a) is provided for Aff, with Source defined in (28b).
a. $\quad[[\mathbf{A f f}]]=\lambda \mathrm{P}_{\mathrm{vt}} \cdot \lambda x \cdot \lambda \mathrm{e} \cdot \mathrm{P}(\mathrm{e}) \& \exists \mathrm{e}^{\prime}\left(\operatorname{exper}(\mathrm{e}) \& \operatorname{Exp}(\mathrm{x})\left(\mathrm{e}^{\prime}\right)\right): \forall \mathrm{e}^{\prime \prime}\left(\mathrm{P}\left(\mathrm{e}^{\prime \prime}\right) \rightarrow \operatorname{Source}\left(\mathrm{e}^{\prime \prime}\right)\left(\mathrm{e}^{\prime}\right)\right) \in$ $\mathrm{D}_{<\mathrm{vt}, \mathrm{et}>}$
b. Source $\rightarrow \lambda$ e. $\lambda \mathrm{e}^{\prime}$. e is the source of $\mathrm{e}^{\prime}$
(ibid.: (63))

\footnotetext{
${ }^{6}$ Beste Kamali (p.c.) notes that for her, under contrastive focus, the experience can also be negated. This is probably true, but we know that (contrastive) focus tends to make otherwise unavailable interpretations available, e.g. boundvariable reading for local persons, obviation of Principle B crosslinguistically. For Turkish, for instance Kural 1992, Öztürk 2005:154-155 note that binding leftward in Turkish is not possible in Turkish in line with the generalization in Pesetsky 1995. However, Turkish leftward scrambling may reconstruct in the presence of contrastive focus. I will continue to assume this contrast to exist. For speakers who may not have the contrast, it would mean that the semantics of this construction is slightly different for them than the one in (28) or section 5, although they have the same syntax.
} 
Source is a function that holds true iff the first event argument is the source of the second event argument. Bosse, Bruening \& Yamada 2012 captures the conventional implicature part after the colon. The observation that part of the meaning of an affected experiencer construction is at-issue while part of it is an implicature, as illustrated in this section, is captured by this split in the meaning: The source information is on the not-at-issue tier, while the affected experiencer is projected on the at-issue tier. Note that the denotation given in ibid. allows the experience to be positive or negative for the affected experiencer. In Turkish, the experience seems to be consistently negative, as hinted by the caused experiencer predicate. I retain this aspect of the original denotation to allow crosslinguistic variation. As such, CEx predicates discussed in Ingason 2016 might be experiencers, rather than benefactives/malefactives, which would follow from the underspecification.

4. Experiencer in the noun phrase. The dative experiencer is introduced in a nominal structure, independently of a verbal property.

4.1. The Category-Defining head Closest to the root is $N$. The category-defining head closest to the root is a nominalizing $n$, as in (29a) and not a verbalizing $v$, which would yield a construction similar to the English gerund (glossing over Voice etc), as in (29b).

(29) a

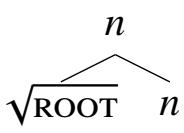

b.

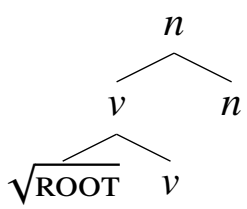

The external status of glclklık 'irritation' or uyuzluk 'annoyance' as a noun is uncontroversial. They bear the overt nominalizing morphology $-l l k$, as well as the possessive morpheme, which in these instances has lost its possessive function (Göksel \& Kerslake 2005: 70; Aslı Göksel, p.c.) and dative case. I leave open the status of dative on the experiencer predicate, as a DP or PP (though as a reviewer suggests its behavior is hard to capture with a PP structure). Also, most of the caused experiencers surface as root nominals, e.g. inat 'spite', hınç 'resentment', haset 'jealousy' or sinir 'anger'.

(30) a

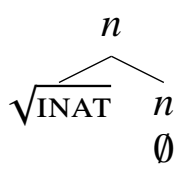

b.

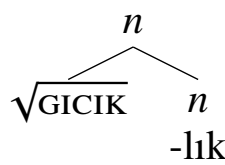

A light-verb construction is needed to use these nominals in a verbal context. Attaching the tense suffix to the nominal leads to ungrammaticality.
a. Son gelişme-ler ben-i gicık et-ti
last development-PL I-ACC irritation do-PST
'The recent developments irritated me.'
b. *Son gelişme-ler ben-i gicık-t1.
last development-PL I-ACC irritation-PST
'The recent developments irritated me.'

Moreover, not all eventualities have a verbal counterpart. The existence of such caused experiencers does not guarantee the existence of a verbal use/counterpart that is made from the same root material. 
For instance, the predicate $h ı n c ̧$ 'resentment' is available as a caused experiencer predicate (32a), yet is ungrammatical in a verbal context, even in a light verb construction, as seen in (32b). ${ }^{7}$
a. Kemal Hasan-a hinc-in-a
öl-me-di.
Kemal Hasan-DAT resentment-POSS-DAT die-NEG-PST
'Kemal didn't die to Hasan's resentment.'
b. *Son gelişme-ler ben-i hınç et-ti.
last development-PL I-ACC resentment do-PST
'The recent developments made me resentful.'

Thus, in a CEx, the category-defining head closest to the root is a nominalizing $n$, as in (29a) and not verbalizing $v .^{8}$

4.2. The TyPe of nouns Allowed. Since the DP in a CEx construction refers to the causing event, not all nouns are appropriate in this position. Contrast (33a) with (33b). ${ }^{9}$
a. Dans ban-a gicıklığ-ın-a-ydi.
dance I-DAT irritation-POSS-DAT-PST
'The dance was to my irritation.'
b. \#Kemal ban-a gicıklı̆̆-1n-a-ydi.
Kemal I-DAT irritation-POSS-DAT-PST
'Kemal was to my irritation.'

No such restriction is observed when the CEx is used in a verbal context, (34), where the mere existence of the individual Kemal might lead to the feeling of irritation, without necessarily him doing anything.
Dans / Kemal ben-i gicik ed-er. dance / Kemal I-ACC irritation do-PST 'Dance/Kemal irritates me.'

4.3. The dative is part of the AffectP/noun phrase. The whole CEx construction behaves as a constituent, based on topicalization, (35), and replacement by a $w h$-word, seen in (36).

\footnotetext{
${ }^{7}$ Case-matching is another diagnostic providing further support to the claim, also discussed in Ingason 2016. I leave that aside for space reasons.

8 Note that although the focus here is to show that CEx is not dependent on a verbal projection, in fact the same argument can be made for simple applicative arguments in Turkish as well, which can occur in a nominal construction (cf. Berro \& Fernández (2018) for Basque). Consider (i).
}

(i) Biletler öğrenciler-e / öğrenciler için bedava!

tickets students-DAT / students for free

'The tickets are free of charge for students.'

For space reasons, I leave the elaboration of this significant point for future research.

9 It is possible to pragmatically coerce it in (33b) to make it acceptable (in Icelandic as well). However, in that case Kemal refers to 'something that Kemal did' or 'some event that featured or involved Kemal' rather than the individual Kemal himself. The same restriction holds for Icelandic, as shown in (i).

$$
\begin{aligned}
& \text { a. Dansinn var stelpunum góð skemmtun. } \\
& \text { dance.the.NOM was girls.the.DAT good entertainment.NOM } \\
& \text { 'The dance entertained the girls well.' } \\
& \text { b. \#Jón var stelpunum góð skemmtun. } \\
& \text { John.NOM was girls.the.DAT good entertainment.NOM } \\
& \text { 'John entertained the girls well.' }
\end{aligned}
$$

(ibid.: 92) 
a. Ban-a gicıklığ-1n-a, onlar - dans et-ti-ler.
I-DAT irritation-POSS-DAT they dance do-PST-PL 'To my irritation, they danced.'

b. *Gicıklı̆̆-ın-a, onlar ban-a _ dans et-ti-ler. irritation-POSS-DAT they I-DAT dance do-PST-PL

Intended: 'To my irritation, they danced.'

(36) Niçin dans et-ti-ler? [Ban-a gıcıklı̆̆-ın-a].

why dance do-PST-PL? [I-DAT irritation-POSS-DAT]

'Why did they dance? [to my irritation = so that I'd get irritated].'

Thus, this construction is not possessor raising (e.g. Adger \& Ramchand 2007). ${ }^{10}$ We can assume the following structure for the purposes of this paper: ${ }^{11}$

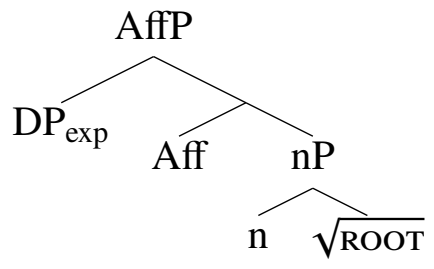

To summarize, caused experiencers differ from applicatives in both interpretational and distributional properties. They are also part of a nominal structure, independent of any verbal structure.

5. Implementation. This section illustrates the syntax and semantics of the CEx and applicatives.

5.1. ApplP. First, let's sketch an analysis for applicatives in Turkish. Adopting the high-applicative structure in (10) by Pylkkänen (2008), I provide the structure in (39) and the denotation in (40) for the example (38) (glossing over the right-headness property of Turkish for expository purposes throughout).

(38) Kemal Leyla-ya şemsiye-yi tut-tu.

Kemal Leyla-DAT umbrella-ACC hold-PST

'Kemal held the umbrella for Leyla.'

${ }_{10}$ As an aside, despite the presence of a possessive morpheme on the caused predicate, it is not possible for the experiencer argument to surface with genitive, (i).

(i) *Kemal Hasan-ın gicıklı̆̆-ın-a bütün gece dans et-ti.

Kemal Hasan-GEN irritation-POSS-DAT whole night dance do-PST

'Kemal danced the whole night to Hasan's irritation.'

Relatedly, an anonymous reviewer asks the interesting question of how we can tell for sure that the morpheme -A on the predicate following the possessive is a dative morpheme. This would mean that there might be a "case matching" between the two nominals involved in this structure, which is not common in Turkish. In addition to probably being the most likely (if not the only) possibility, this assumption is supported by the fact that some speakers also allow ablative, i.e. -dAn, besides dative case (with the caveat that ablative case favors the other salient reading mentioned in fn. 2). The same reviewer also questions the structure of this larger structure, which as I hinted in fn. 11, could be a DP or PP, but I leave aside for future research.

11 Putting aside some details such as whether the overall structure is a DP or PP, which would make no difference to the semantic derivation. 
(39)

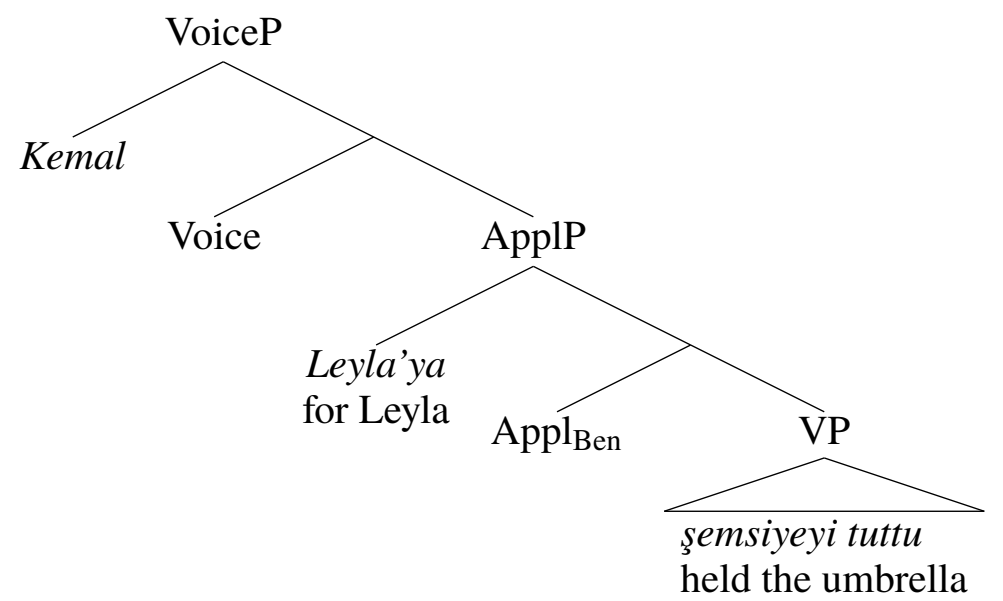

(40) a. $[[\mathbf{V P}]]=\lambda$ e.hold(e) \& Theme(e, the umbrella)

b. $[[\mathbf{A p p l P}]]=\lambda$ e.Benef(e, Leyla) $\&$ hold(e) \& Theme(e, the umbrella)

c. $\quad[[$ VoiceP $]]=\lambda$ e.Agent $(\mathrm{e}, \mathrm{Kemal}) \&$ Benef(e, Leyla) \& hold(e) \& Theme(e, the umbrella)

5.2. AfrP. Recall that Bosse, Bruening \& Yamada (2012) provide the following denotation for Aff.

(41) a. $\quad[[\mathbf{A f f}]]=\lambda \mathrm{P}_{\mathrm{vt}} \cdot \lambda x \cdot \lambda \mathrm{e} \cdot \mathrm{P}(\mathrm{e}) \& \exists \mathrm{e}^{\prime}\left(\operatorname{exper}(\mathrm{e}) \& \operatorname{Exp}(\mathrm{x})\left(\mathrm{e}^{\prime}\right)\right): \forall \mathrm{e} "\left(\mathrm{P}\left(\mathrm{e}^{\prime \prime}\right) \rightarrow \operatorname{Source}\left(\mathrm{e}^{\prime \prime}\right)\left(\mathrm{e}^{\prime}\right)\right) \in$ $\mathrm{D}_{<\mathrm{vt}, \mathrm{et}>}$

b. Source $\rightarrow \lambda e . \lambda e^{\prime}$. e is the source of e'

(ibid.: (63))

In Turkish, the eventuality is overt, thus we need to slightly modify the original denotation, and feed Aff a second argument of type $<\mathrm{s}, \mathrm{t}>$, Q below:

$$
\begin{gathered}
{[[\mathbf{A f f}]]=\lambda \mathrm{P}_{\mathrm{st}} \cdot \lambda \mathrm{x} \cdot \lambda \mathrm{Q}_{\mathrm{st}} \cdot \lambda \mathrm{e} \cdot \mathrm{Q}(\mathrm{e}) \& \exists \mathrm{e}^{\prime} \cdot \mathrm{P}\left(\mathrm{e}^{\prime}\right) \& \operatorname{Exp}\left(\mathrm{e}^{\prime}, \mathrm{x}\right): \forall \mathrm{e}^{\prime \prime}\left[\mathrm{Q}\left(\mathrm{e}^{\prime \prime}\right) \rightarrow \operatorname{Source}\left(\mathrm{e}^{\prime \prime}\right)\left(\mathrm{e}^{\prime}\right)\right) \epsilon} \\
\left.\left.\mathrm{D}_{<\mathrm{st}, \mathrm{et}>}\right]\right]^{12}
\end{gathered}
$$

Given this adaptation, the semantic denotation for (43) is provided in (44).

(43) Hasan-a gicıklığ-in-a

Hasan-DAT irritation-POSS-DAT

'to Hasan's irritation'

(44) a.

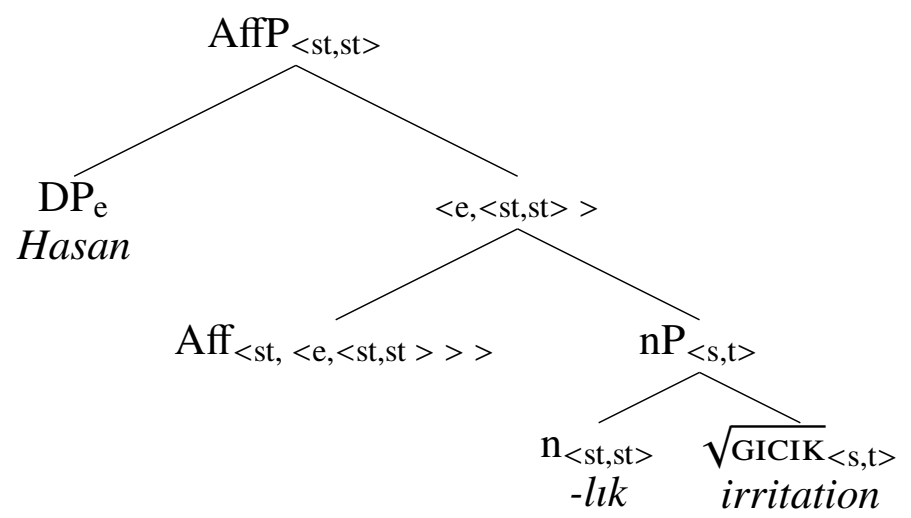

b. $\quad[[\sqrt{\text { GICIK }}]]=\lambda$ e.gicık $(\mathrm{e})$

c. $\quad[[\mathbf{n}]]=\lambda \mathrm{f}_{<\mathrm{st}, \mathrm{st}>\mathrm{f}}$

12 Bosse, Bruening \& Yamada 2012 use the denotation $v$ for eventuality, here I use $s$. 


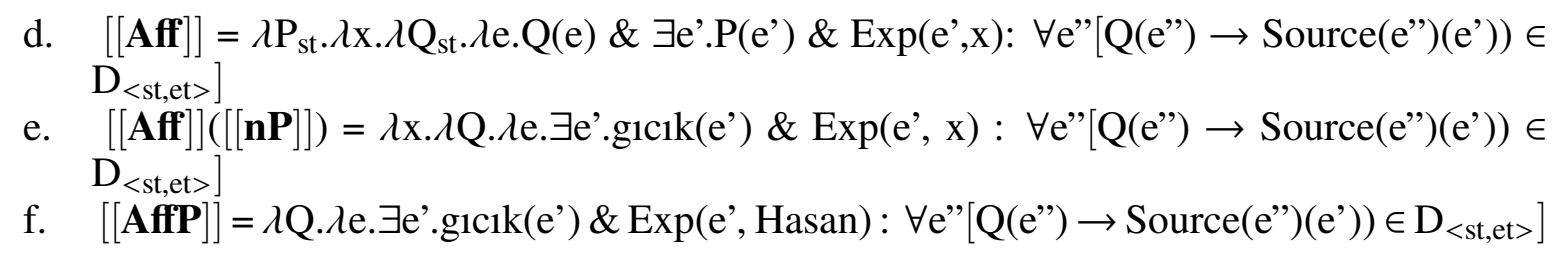
Several remarks are in order with respect to (44). It diverges from Ingason 2016 in two crucial ways. Ingason (2016: 88) encodes the causative semantics on the category-defining head $n$, thus provides the following denotation for it.

$$
\left[\left[\mathrm{n}_{\text {cause }}\right]\right]=\lambda \mathrm{P}_{\mathrm{st}} \cdot \lambda \mathrm{e} \cdot \exists \mathrm{e}^{\prime}\left[\mathrm{P}\left(\mathrm{e}^{\prime}\right) \& \operatorname{CAUSE}\left(\mathrm{e}, \mathrm{e}^{\prime}\right)\right]
$$

I choose to encode the causative semantics on the Affect head itself rather than $n$. Instead, here the nominalizing head is taken to be a semantically vacuous item as denoting the identity function of the appropriate type, as illustrated in (44c). Secondly, Ingason represents the relationship between the causing event and the caused event as CAUSE in the denotation (Parsons 1990, Pylkkänen 2008). I follow Bosse, Bruening \& Yamada 2012 and encode this relationship via Source defined in (44d). To repeat, this function is true iff the first event argument is the source of the second event argument. Bosse, Bruening \& Yamada's (2012) denotation also represents the conventional implicature after a colon. This is due to the observation that part of the meaning of an affected experiencer construction is at-issue, while part of it is an implicature. In this denotation, the source information is on the not-at-issue tier, while the affected experiencer is projected on the at-issue tier.

The tree in (46) illustrates the structure until the point where AffP adjoins to ApplP, ${ }^{13}$ and the denotations of them are provided in (47).

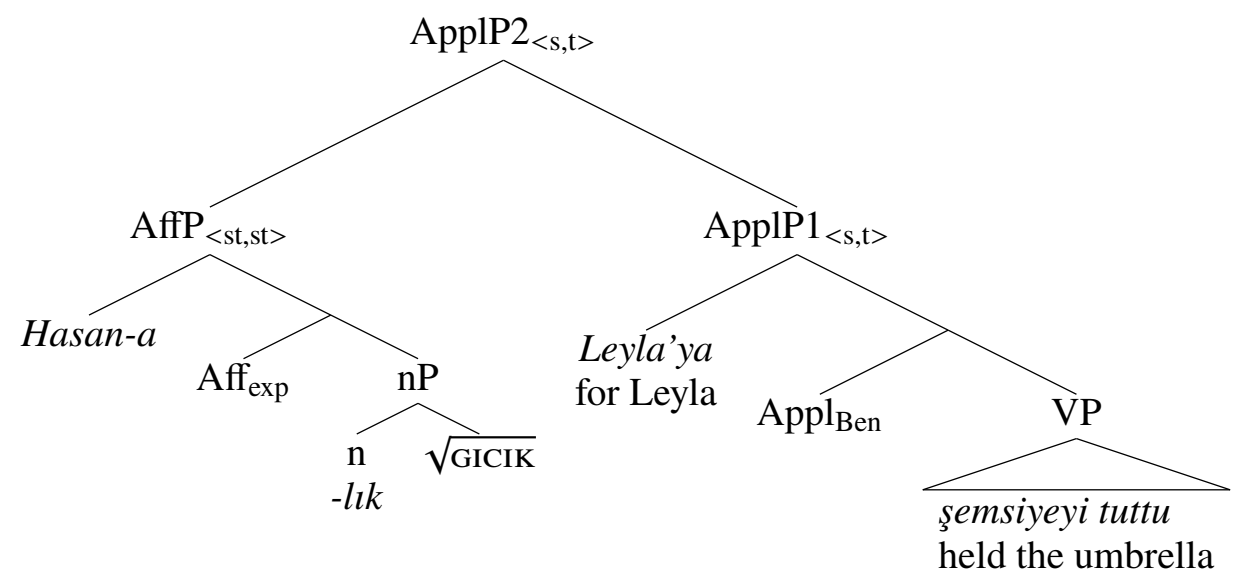

(47) a. $\quad[[$ ApplP1 $]]=\lambda$ e.Benef(e, Leyla) \& hold(e) \& Theme(e, the umbrella $)$

b. $\quad[[\mathbf{A f f P}]]=\lambda \mathrm{Q} \cdot \lambda \mathrm{e} \cdot \exists \mathrm{e}^{\prime} \cdot \operatorname{gic1k}\left(\mathrm{e}^{\prime}\right) \& \operatorname{Exp}\left(\mathrm{e}^{\prime}\right.$, Hasan $\left.): \forall \mathrm{e}^{\prime \prime}\left[\mathrm{Q}\left(\mathrm{e}^{\prime \prime}\right) \rightarrow \operatorname{Source}\left(\mathrm{e}^{\prime \prime}\right)\left(\mathrm{e}^{\prime}\right)\right) \in \mathrm{D}_{<\mathrm{st}, \mathrm{et}>}\right]$

AffP and ApplP combine by Functional Application; that is, we simply conjoin the terms of each predicate.

(48) $[[$ ApplP2 $]]=\lambda e \cdot h o l d(e) \& \operatorname{Benef}\left(e\right.$, Leyla) \& Theme(e, the umbrella) \& $\exists e^{\prime} \cdot$ gicik(e') \& Exp(e', Hasan): $\forall$ e"(hold(e") \& Benef(e", Leyla) \& Theme(e", the umbrella) $\rightarrow$ Source(e")(e'))

After ApplP2 combines with Voice and the agent is introduced via Event Identification (Kratzer 1996), which in the example (49) is Kemal, we get the assertion and conventional implicature in (50) for this sentence.

13 adjunction of AffP to ApplP is supported by binding facts, which I leave out for space reasons. 


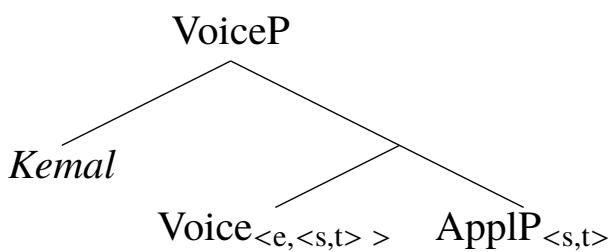

(50) Assertion and Implicature:

- Assertion: $\exists$ e.(e is an event of Kemal holding the umbrella for Leyla) and $\exists \mathrm{e}^{\prime}$.(e' is an event of Hasan having a psychological experience of irritation).

- Implicature: Any event e" that is holding an umbrella (for Leyla) would be the source of Hasan's experiencing e'.

6. Conclusions. This paper investigates two types of dative arguments in Turkish and suggests that they belong to distinct categories.

The first type is categorized as a caused experiencer (or affected experiencer) mainly following a similar construction in Icelandic (Ingason 2016). These experiencers are introduced by the Affect head of Bosse \& Bruening (2011) and Bosse, Bruening \& Yamada (2012) internally to nominal structures. The affected experiencers are distinguished from the applicative arguments on the basis of several syntactic and semantic considerations. The applicative argument is introduced in Spec,ApplP. I reconcile the semantic computations suggested by (Ingason 2016) and Bosse, Bruening \& Yamada (2012) to derive the desired meanings of these constructions and their interaction with other elements in the structure.

\section{References}

Adger, David \& Gillian Ramchand. 2007. Psych nouns and the structure of predication. In Proceedings of NELS 36, 89-102. Amherst, MA: GLSA.

Berro, Ane \& Beatriz Fernández. 2018. Applicatives without verbs. Natural Language \& Linguistic Theory. 1-45. https://doi.org/10.1007/s11049-018-09437-4.

Bosse, Solveig \& Benjamin Bruening. 2011. Benefactive versus experiencer datives. In Mary Byram Washburn, Katherin McKinney-Bock, Erika Varis, Ann Sawyer \& Barbara Tomaszewicz (eds.), Proceedings of the 28th West Coast Conference on Formal Linguistics, 69-77.

Bosse, Solveig, Benjamin Bruening \& Masahiro Yamada. 2012. Affected experiencers. Natural Language \& Linguistic Theory 30(4). 1185-1230. https://doi.org/10.1007/s11049-012-9177-1.

Göksel, Asl \& Celia Kerslake. 2005. Turkish: A comprehensive grammar. Routledge.

Ingason, Anton Karl. 2016. Realizing morphemes in the Icelandic noun phrase. University of Pennsylvania PhD thesis.

Kratzer, Angelika. 1996. Severing the external argument from its verb. In Johan Rooryck \& Laurie Zaring (eds.), Phrase structure and the lexicon, 109-137. Dordrecht: Kluwer.

Kural, Murat. 1992. Properties of scrambling in turkish. manuscript. UCI.

Öztürk, Balkz. 2005. Case, referentiality and phrase structure. John Benjamins.

Parsons, Terence. 1990. Events in the semantics of english: a study of subatomic semantics. Cambridge, MA: MIT Press.

Pesetsky, David. 1995. Zero syntax. Cambridge, MA: MIT Press.

Potts, Christopher. 2005. The logic of conventional implicatures. Oxford University Press.

Pylkkänen, Liina. 2002. Introducing Arguments. MIT PhD thesis.

Pylkkänen, Liina. 2008. Introducing arguments. Cambridge, MA: MIT Press. https://doi.org/10. 7551/mitpress/9780262162548.001.0001.

Tonyal, Nil. 2015. Non-structural datives in Turkish. Boaziçi University MA thesis. 